\title{
Mathematical Equations for Reducing Water Pollution Problems among Poultry Production Clusters in Nong Khai Province, Thailand
}

\author{
Worapol Aengwanich1, Thongchai Boonsorn'1, Komvut Thammasar ${ }^{2}$ \\ ${ }^{1}$ Stress and Oxidative Stress in Animal Research Unit, Faculty of Veterinary Sciences, Mahasarakham University, \\ Maha Sarakham, Thailand \\ ${ }^{2}$ Nong Khai Provincial Livestock Office, Department of Livestock Development, Nong Khai, Thailand \\ Email: worapol.a@msu.ac.th
}

Received December 2013

\begin{abstract}
Poultry production clusters (PPC) in Nong Khai raise layer chickens in the poultry houses constructed over fish ponds. Layer farmers use chicken manure to feed their fish. However, unbalance between chicken raising and the size of fish pond or number of fish results in low water quality, which affects fish production and the community's public water resource. In this field study, data was collected from layer farms in three poultry production clusters in Nong Khai province in the northeast of Thailand (a total of 90 farms) between April and August 2013. Data collected consisted of observations of dissolved oxygen (DO) values of water in the fish ponds, the number of egg-laying chickens raised above the fish ponds, the number of fish and size of the fish ponds. When all of these four observations were analyzed, mathematical equations for calculating the number of chickens raised, the number of fish per one rai $\left(1600 \mathrm{~m}^{2}\right)$, and the size of pond suitable for the number of chickens and fish were obtained as follows: 1) number of fish/rai $=\mathbf{5 7 9 6}+$ 1097 (size of pond) $\left.\left(R^{2}=0.71\right), 2\right)$ number of chicken/rai $=513+223$ (size of pond) $\left(R^{2}=0.48\right)$ and 3 ) size of pond $=-0.328474+0.000262($ Fish $)+0.00117($ Chicken $)\left(R^{2}=0.40\right)$. When pond $=$ desired pond size, fish $=$ number of fish to be raised and chicken $=$ number of chickens to be raised.
\end{abstract}

\section{Keywords}

Mathematic Equation; Water Pollution; Poultry Production Clusters; PPCs; Fish; Pond; Thailand

\section{Introduction}

Poultry have been essential livestock in the Thai people's way of life for a long time. Historically, poultry farming for commercial purposes in Thailand started in 1970 (Christensen, 1992) and the poultry business has gradu-

How to cite this paper: Aengwanich, W. et al. (2014). Mathematical Equations for Reducing Water Pollution Problems among Poultry Production Clusters in Nong Khai Province, Thailand. Journal of Geoscience and Environment Protection, 2, 48-51. http://dx.doi.org/10.4236/gep.2014.22008 
ally grown since then. Before 2004, Thailand was among the world's leaders in chicken meat exports (Tiensin et al., 2007). However, approximately 90 percent of domestic producers remained small farms (Heft-Neal et al., 2009), mainly located in rural villages where backyard farming was largely employed. A study on poultry farming conducted by Aengwanich et al. (2012) revealed that poultry production clusters (PPCs) in Thailand were composed of small-scale farmers and these poultry production clusters were defined as "areas of concentrated poultry production in rural areas usually separated from residential areas-where farms practice certain economies of scale and use comparative advantages of localities, resulting in improvements to and increased intensification of poultry production. The farms in the cluster apply standard biological safety and environmentally friendly practices and install related facilities. Major drives for the formation of PPCs and changes to PPCs include government programs for enhanced bio-security at both national and local levels, extended families, cooperatives and improved links to contracting companies that supply inputs and purchase outputs and outbreaks of highly pathogenic avian influenza”. In Nong Khai province in the northeastern region of Thailand, such type of poultry production clusters with layer chicken houses constructed over fish ponds can be found throughout the province. However, if the ratio of chickens in the houses constructed over the fish ponds and the number of fish in the ponds is unsuitable, the consequence is polluted water in the ponds. Moreover, if such water is released to public water sources of the communities, it will pollute the community's water sources. Therefore, the purpose of this study is to examine and find mathematical equations for calculating a suitable ratio of the number of chickens and the number of fish released into the ponds to prevent impact on water quality.

\section{Materials and Methods}

\subsection{Research Site}

Nong Khai province is located in the upper northeastern region. The area is narrow, stretching along the bank of the river Mekong with approximate length of $210.6 \mathrm{~km}$. On the opposite bank of the river Mekong is Laos. Nong Khai is 615 kilometers away from Bangkok, and 25 kilometers from Vientiane, the capital city of Laos. In the Nong Khai province area the important poultry raised are layer chickens, most of the farms are in three main districts, i.e. Muang district, Tha Bo district, and Sri Chiang Mai district with approximately 280 farms. The farming pattern is clusters of 50 - 100 farms that are located away from the communities, dispersing near natural water sources e.g. large lakes or areas with irrigation systems and drainage systems or on one's own land. A notable characteristic of the layer chickens production in Nong Khai province is that they keep fish with hens, building coops upon fish ponds. The roof of the barn was made of grass or metal, the walls, bamboo. The floor of the barn was built to leave holes to allow the feces of the chicken to fall into the ponds, serving as fish feed. The fish they keep are Nile Tilapia and fish in carp family. Thus the farmers have 2 sources of income: from the layer chickens and from the fish. Around the fish ponds there were trees.

\subsection{Collecting Data, Lab Test and Statistical Analysis}

A random sampling study was conducted in 90 poultry farms (during April-August 2013) in Thasamran village (30 farms), Thabo district; Wieng kook village (30 farms) and Kok Pla Faang Village (30 farms), Muang district, Nong Khai. Next, data was collected from the farmers on the number of chickens raised over the ponds, the number of fish released in the pond and the pond sizes.

\subsubsection{Laboratory Investigation}

Dissolved oxygen (DO) was measured by using a hand-held Dissolved Oxygen Meter, Model 8403(AZ $\left.{ }^{\circledR}\right) 2$. The measurement was carried out by dipping the probe 30 centimeters deep into the pond in the poultry house area for 3 minutes, then reading and recording.

\subsubsection{Statistical Analysis}

Data on DO in water, the number of chickens and fish raised in the pond and pond sizes were used to calculate and find the regression equation between the number of chicken and fish raised and the pond size to find the ratio between the number of chickens, number of fish and pond sizes suitable for raising chickens together with fish. 


\section{Results}

The field data collected included the DO values of the water in the fish ponds, the number of egg-laying chickens raised over the fish ponds, the number of fish released into the ponds and the sizes of the fish ponds. When such data was statistically analyzed, equations were obtained for calculating the number of chickens raised over the ponds and the number of fish per rai, as well as the suitable fish pond size for any given numbers of chickens and fish as follows:

1) Number of fish/rai $=5796+1097$ (size of pond) $\left(R^{2}=0.71\right)$

2) Number of chicken/rai $=513+223$ (size of pond) $\left(R^{2}=0.48\right)$

3) Size of pond $=-0.328474+0.000262($ Fish $)+0.00117$ (Chicken) $\left(R^{2}=0.40\right)$

When pond $=$ desired pond size

Fish = number of fish to be raised

Chicken $=$ number of chickens to be raised

\section{Discussion}

An analysis of the field data collected, including DO values of water in the fish ponds, the number of egg-laying chickens raised in the houses constructed over the fish ponds, the number of fish released into the ponds, and the sizes of fish ponds of poultry production groups in Nong Khai province, Thailand, yielded three mathematical equations: 1) an equation for calculating a suitable number of fish to be released into the ponds per rai; 2) an equation for calculating a suitable number of chickens to be raised per rai; and 3) an equation for calculating the fish pond size for any given numbers of fish and chickens cultured. The statistical analysis showed that correlation coefficient $(\mathrm{R})$ of the number of fish to be released into the ponds and the number of chickens in the houses over the ponds was equal to 0.95 , which was a high value. This means if the number of chickens is increased, the number of fish in the ponds must be increased too.

The equations obtained from the above study are consistent with the study of Njoku and Ejiogu (1999), who conducted a study on raising chickens over fish ponds, finding that one hectare (6 rai and 400 square meters) was able to accommodate 1500 broilers. According to the equations obtained by the present study, if layer chickens are raised over a pond of one hectare in size, a total of 1907 chickens can be raised. It can be seen that the number of egg-laying chickens obtained by the calculation is higher than the number reported by Njoku and Ejiogu (1999). However, such report did not include a study of oxygen level in the water, which indicates water quality or the occurrence of pollution in the fish ponds.

The coefficient of determination $\left(\mathrm{R}^{2}\right)$ for the number of fish released per rai, the number of chickens raised over one rai of fish pond, and the pond size calculated from the numbers of fish and chickens equal $0.71,0.48$ and 0.40 , respectively. Those values are found to be at a moderate level. The reason for such moderate values of the coefficient of determination $\left(\mathrm{R}^{2}\right)$ is that the data collected for the analysis were gathered from the actual farming conditions where no variables were preset. Moreover, the layer farms used the original farming approach and the farmers did not change the ratio of fish and chickens as well as water in the fish ponds to become suitable; therefore, $\mathrm{R}^{2}$ values obtained were moderate. A means to increase the equations' accuracy and preciseness is an intervention to encourage the farmers to adjust their ratio of chickens raised over the fish ponds and the number of fish released into the fish ponds in accordance with the abovementioned equations as well as to keep the fish ponds clean. Then, measure the observations and use these observations to constantly calculate the equations. When the ratio of chickens and fishes are properly adjusted, the $\mathrm{R}^{2}$ values of such equations are likely to gradually increase.

\section{Conclusion}

According to the field study in the PPCs in the province of Nong Khai where egg-laying chickens are raised over fish ponds, it was found that unbalance between the number of chickens and the number of fish in the ponds resulted in water pollution both in the fish ponds and the public water sources. When field data, including DO values of water in the fish ponds, the number of chickens raised over the fish ponds, the number of fish released into the fish ponds, and sizes of the fish ponds, were collected and statistically analyzed, the equations for calculating the number of chickens raised and the number of fish released per rai as well as the sizes of fish ponds suitable for any given numbers of chickens and fish were obtained as follows: 
1) Number of fish/rai $=5796+1097$ (size of pond) $\left(R^{2}=0.71\right)$

2) Number of chicken/rai $=513+223$ (size of pond) $\left(R^{2}=0.48\right)$

3) Size of pond $=-0.328474+0.000262$ (Fish) +0.00117 (Chicken) $\left(\mathrm{R}^{2}=0.40\right)$

When pond $=$ desired pond size

Fish $=$ number of fish to be raised

Chicken $=$ number of chickens to be raised

\section{Acknowledgements}

This research was funded by International Development Research Centre; Foreign Affairs, Trade and Development Canada (through the Global Health Research Initiative); and the Australian Agency for International Development.

\section{References}

Aengwanich, W., Intarakhamhaeng, M., Wandee, J., Nongbua, T., Chaiyasak, S., Srikot, P., Thammasar, K., Junsanitsri, N., Sritongtuam, K., \& Tawinwaang, T. (2012). Poultry Production Clusters (PPCs) after AI Outbreaks in Thailand: Past, Present and Future Direction. International Journal of Poultry Science, 11, 541-550. http://dx.doi.org/10.3923/ijps.2012.541.550

Christensen, S. (1992). The Role of Agribusiness in Thai Agriculture: Toward a Policy Analysis. TDRI Quartery Review, 7, 3-9.

Heft-Neal, S., Kahrl, F., Otte, J., \& Roland-Holst, D. (2009). Assessment of Smallholder Indigenous Poultry Producer Viability in Thailand. Mekong Team Working Paper No. 9. Department for International Development.

Njoku, D. C., \& Ejiogu, C. O. (1999). On-Farm Trials of an Integrated Fish-Cum-Poultry Farming System Using Indigenous Chickens. Aquaculture Research, 30, 399-408. http://dx.doi.org/10.1046/j.1365-2109.1999.00325.x

Tiensin, T., Nielen, M., Songserm, T., Kalpravidh, W., Chaitaweesub, P., Amonsin, A., Chotiprasatintara, S., Chaisingh, A., Damrongwatanapokin, S., Wongkasemjit, S., Antarasena, C., Songkitti, V., Chanachai, K., Thanapongtham, W., \& Stegeman, J. A. (2007). Geographic and Temporal Distribution of Highly Pathogenic Avian Influenza a Virus (H5N1) in Thailand, 2004-2005: An Overview. Avian Disease, 51, 182-188. http://dx.doi.org/10.1637/7635-042806R.1 